\title{
家鬼肺炎球菌皮内感染症のペニシリン治療に及ぼす コーチッ゙ンの影響について
}

鹿応義塾大学医学部内科学教空（指導 三方一沢教授）

榎 本 新 市

\section{THE EFFECTS OF CORTISONE ON PENICILLIN THERAPY \\ OF EXPERIMENTAL INTRADERMAL PNEUMOCOCCUS INFECTION}

BY

\section{Shinichi Enomoto}

Dep. Int. Med., School of Medicine, Keiō University

(Prof.: I. Mikata)

\begin{abstract}
梗概 感染症の抗生㓮治療に及代す副腎ステロイドの影響をみる目的で, Goodner の方法に做い

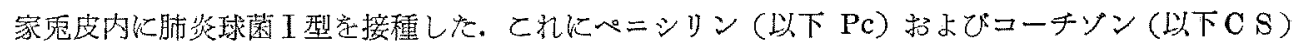

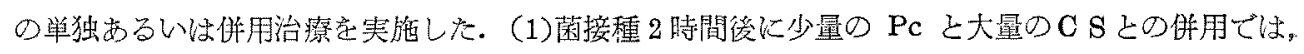
局所所見に若干の效果室みるが, 菌血症は助長される.（2)同樣, 大量のPc 算独治療では, 菌血

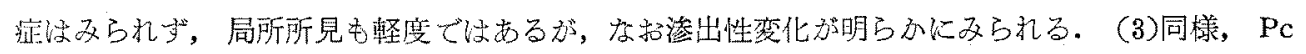

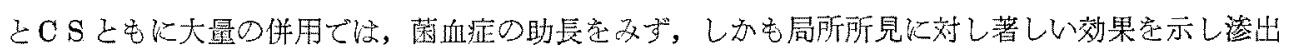

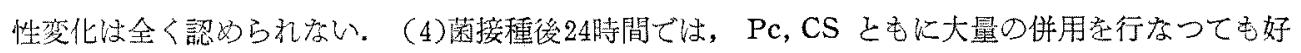
影響は得られなかつた. 結論的には, Pc, CS の併用は感染早期に, しかも Pc, CS ともに大量使 用した場合にの及好影響尘得ることができる。
\end{abstract}

\section{I 緒 言}

感染症に対する抗生削の萑義は，近年における そのめざましい発達とともに大きな役割を演じて きた。しかしながら，抗生剂本来の使命で女る疬 原体自身に作用する機序のみによつては，な扔治 療效果に充分な解決を与えること次できない面が 多々あることが知られ，今まで，比較的等閑視さ れていた宿主生体側の因子が注目されるようにな つた.

この宿主生体侧の要因に重大な影響を与える意 味に挍いて，下垂体副雉系ホルモンの存在が注目 されるょうになり, 感染症の治瘵にも応用せんと する試みが感んとなつてきた。
感染症に対するこれらのホルモンの影響はきわ めて複雑であるが,一般的には、このホルモンの 有する渚明な抗炎症作用を利用して, 症狀の寛解 を期待しているものである。

しかし他方，このホルモンは炎症症狀を隐蔽 し，また敗血症の脬発，生体防蒚力の減弱等が 周時にみられることが知られており，諸家の貑 告2 20)もまちまちである。

そこで，著者は感染症の抗生都治療に及ほ文副 腎ステロイドの影響をみる目的で, Goodner ${ }^{1) の ~}$ 方法に做い, 蒙東に肺炎球菌皮内感染症学远せ しめ，抗生剂および副腎ステロイドの併用投与を 試み，その治療成績を检討してみて，與味ある知 
見を得たのでここに報告する。

\section{II 実験材料および実験方法}

1) 実験動物：体重やく $2 \mathrm{~kg}$ の健常成熱家雭 で, 実駼前，耳静脈より採血し流血中に肺炎球菌 のないことを確かわた。

2)使用菌株ならびに菌液：使用肺炎球菌は I 型 $100 \mathrm{~A}$ 株で， $1.0 \%$ ブウ精加肉水ブイヨン に $\sim 8$ 時間培盖した菌液 $0.1 \mathrm{cc}$ を, 腹部皮内に 接種することに一定した. その菌量は1〜 $6 \times 10^{8}$

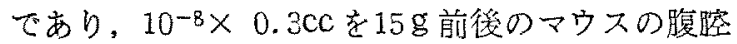
内接種で，72時間以内に繁す毒力を有する。

3）実歌力法：上記家震の腹部の毛を切り, さらに硫化バリウムで脱毛し, 前記の菌液 $0.1 \mathrm{cc}$ を腹部の汪ぶ中央皮内に接種し，歪日より腹部の 局所区応, 体温, 体重さらに耳静脈より採血し, 菌血症の有無学連日測定した。

流血中の肺炎球菌の証明は，耳静脈より埰血し た血液 $1.00 \mathrm{c}$ 混釈平板培荃とした。また部の 群では, 感染後 $1,2,5,8,12,18,24$, $36 ， 48 ， 60 ， 72 ， 84 ， 96$ 時間に菌血症の有寒を観 察した。

Fig. 1. Mode of treatment.

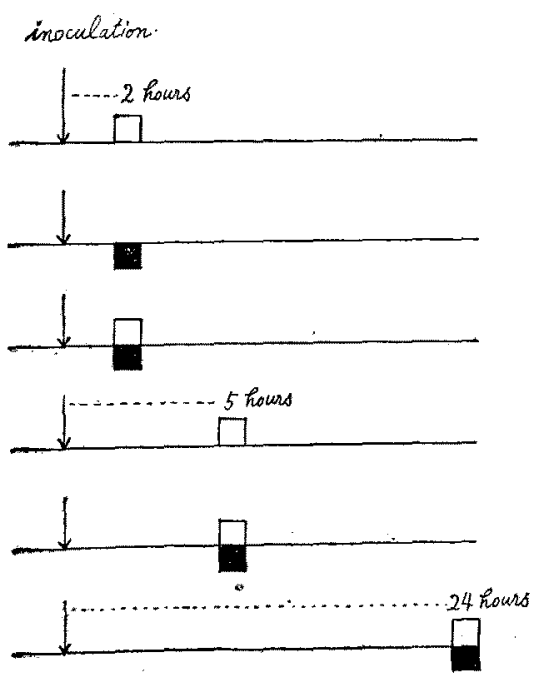

Penaras: IPendilition Cortisone
なお本㬰驗では，局所の皮感帘化を主としてみ るために4日間の観祭とし，これを屠殺し，組織 学的検索ならぴに藏器の菌检出を行なった。さら にまた，感染後 $2 ， 5 ， 12 ， 24 ， 48$ 時間の各群も 屠殺し，前記の检索を笑施した。したがつて，死

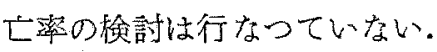

4)，使用薬剤：ペニシリンは，結晶ペニシリ ン Gナトリウム(以下 Pc と略す), 㲘濁水性プ ロカインペニシリン(以下 PPc と略す), 副腎ス テロイドとしては, コーチソンアヤテート（以下 O S と略す)を使用した。

5）治療型式：第1図に示すごとく，菌接種 後 2 時間， 5 時間，24時間に開始とした。Pc は 1,000筆位 (以下Uと略す) あるいは PPc 5 万U むしくは30万Uを，1日1回筋注し，CSは PC と同時に $0.5 \mathrm{mg}$ しくは25mgを筋注した。

\section{III 実験成續}

皮清の变化は，次の制定基準により分類した。 すなわち，肉眼的に発赤の強さが著明なもの，腫 脹の大きさが $5 \mathrm{~cm}$ 以上のもの，墩死の有無によ り分けた。以上の3者を有するものを(H)，2 者 を有するものを(十),一つのみのものを(十), 発 赤が微かで, 腫脹の大きさむ小さいもは（士） として，無变化すなわち（一）と同様に扱つた。

また，体温上昇 $1.0^{\circ} \mathrm{C}$ 以上を $(+)$, 上昇 $1.0^{\circ} \mathrm{C}$ 以下を(一), 体重減少 $100 \mathrm{~g}$ 以上を $(+)$, それ以 内を（一）として表示した。

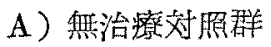

同僚柳沢 ${ }^{2)}$ によれば，第 I 表に示すごとく，14 例中すべてのものは，腹部局所の発赤腫脹は著明 に出現し，6例に淕死が䛑められる。菌血症はま ちまちで，3例は24時間以後，菌陰性である，菌 数は，多くは 100 集落以下であり，時間とともに 漸次減少して行く倾向がみられる，局所の菌陽性 は 4 例に, 体重減少は 9 例, 体温上昇は全例に認 められている。

B) Pc 単獨治療

1) 2 時閒後治療開始群
a) PPc 5 万U 
Table I. Non treated control group by Yanagisawa ${ }^{2)}$

\begin{tabular}{|c|c|c|c|c|c|c|c|}
\hline \multirow{2}{*}{$\begin{array}{l}\text { No. of } \\
\text { rabbits }\end{array}$} & \multirow{2}{*}{$\begin{array}{l}\text { Skin } \\
\text { change }\end{array}$} & \multicolumn{4}{|c|}{$\begin{array}{l}\text { Bacterial number } \\
\text { In Glood per c.c. }\end{array}$} & \multirow{2}{*}{$\begin{array}{l}\text { Weight - } \\
\text { lows }\end{array}$} & \multirow{2}{*}{$\begin{array}{l}\text { Rise of } \\
\text { temperature }\end{array}$} \\
\hline & & 24 & 48 & 72 & $\left(\begin{array}{l}\text { houm } \\
96\end{array}\right.$ & & \\
\hline 274 & \# & $\frac{47}{5}$ & $\frac{10}{3}$ & 6 & $\begin{array}{c}24 \\
0\end{array}$ & $\begin{array}{l}+ \\
+\end{array}$ & $\begin{array}{l}+ \\
+\end{array}$ \\
\hline 288 & H & $3 t$ & 68 & 3 & 22 & + & + \\
\hline 303 & \# & 12 & 100 & 800 & $2000 \uparrow$ & + & \\
\hline $3 / 1$ & H & 280 & $2000 t$ & $2000 \uparrow$ & 2000 ? & + & + \\
\hline & H\# & 32 & 1040 & 200 & 560 & 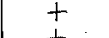 & + \\
\hline 357 & +\# & 0 & 0 & 0 & 0 & + & + \\
\hline 358 & m & 340 & 96 & $2000 t$ & $1 / 2$ & \pm & \\
\hline 412 & \# & 0 & 26 & 0 & 0 & $\bar{t}$ & + \\
\hline 417 & $\pi$ & 0 & 4 & $\begin{array}{l}0 \\
0\end{array}$ & 0 & - & + \\
\hline $\begin{array}{l}432 \\
433\end{array}$ & $\mathrm{HH}$ & $1 / 4$ & 0 & 4 & 0 & 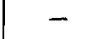 & + \\
\hline 434 & \# & 0 & 0 & 0 & 0 & - & + \\
\hline 435 & H & & 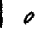 & 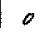 & 0 & - & + \\
\hline
\end{tabular}

Remarks: Weightloss was indicate as $(+)$ if it was above $100 \mathrm{~g}$ and $(-)$ below $100 \mathrm{~g}$ from initial weight. Rise of temperature was indicate as $(t)$ if it was above $1.0^{\circ} \mathrm{C}$ and as ( - ) if it was within $1.0^{\circ} \mathrm{C}$ from initial body temperatare.

第I表A）（a）に示すごとく，皮膚の変化は 対腙よりかなり軽減されている。9 例中，㯖死を 有するもの，局所の菌陽性のものは 1 例もみられ ず，体重減少は最高90gで，他のもの汪減少が注 とんどみられなかつた。体温上昇は2例で，他の 7 例はいずれも $0.7^{\circ} \mathrm{C}$ 以下であつた。

一方菌血症は，Pc 投与後は菌はすみやかに消 失するが，中 2 例には，48時間に18抽よび24集落 檢出されたが、続いては検出されていない。これ らはいずれも体温上昇例である。

b) Pc 1,000 U

発赤腫脤の局所変化は，なおかなり著明であ り，対照とほぶ同㥞である。体温上昇柱全例にみ られ，局所の菌は2例に認められる。菌血症も対 炤と大差がなく，No. 521 では，48時間に2,000 集落以上で96時間で死亡しており，菌检出は第 $\mathbb{I}$ 表A）（b）のごとくである。

2) 5 時間後治療開始群

菌接種 5 時間後に治療を開始した 5 例では，第 II表B）に示すように, PPc 30万Uの大量を使用 したにかつわらず，皮膚の変化はかなり著明であ
Table II. Group treated with Penicillin alone.

A) Group in which trestment was initiated 2 hours after in oculation.

(a) PPC 50,000U.

\begin{tabular}{|c|c|c|c|c|c|c|c|}
\hline No. of & & & & r & & 4 biab & 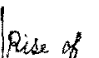 \\
\hline rabbits & Change & 24 & 48 & 77 & of & & Ttemperatare \\
\hline 467 & 1 & $\because$ & 0 & 0 & 0 & I & - \\
\hline 68 & & 0 & $:$ & $:$ & $\mid \begin{array}{l}0 \\
0\end{array}$ & - & $=$ \\
\hline & & 0 & 0 & 0 & 0 & - & \\
\hline 475 & & 0 & 0 & 0 & 0 & - & - \\
\hline 476 & H & 0 & 18 & 0 & 0 & & + \\
\hline 478 & 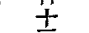 & $:$ & 0 & 0 & 10 & - & \pm \\
\hline & & 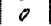 & & 0 & 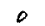 & & 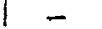 \\
\hline
\end{tabular}

(b) $\mathrm{pc} 1,000 \mathrm{u}$.

\begin{tabular}{l|l|c|c|c|c|c|c}
\hline 520 & $H$ & 0 & 8 & 4 & 0 & - & + \\
521 & $H$ & 84 & 2000 & 20001 & death & + & + \\
522 & $H$ & 13 & 0 & 4 & 0 & - & + \\
523 & $H$ & 3 & 2 & 5 & 0 & - & +
\end{tabular}

B) Group in whish treatinent was intitiated 5 hours oftur inoculation.

(a) PPC 300,000 U.

\begin{tabular}{l|l|l|l|l|l|l|l}
\hline 403 & +1 & 0 & 0 & 0 & 0 & - & - \\
404 & +1 & 0 & 0 & 0 & 0 & - & + \\
405 & +1 & 0 & 0 & 0 & 0 & - & - \\
415 & +1 & 0 & 0 & 0 & 0 & + & -
\end{tabular}

つた１例に局所から菌を検出したが，血中菌は 96時間まで全例陰性であつた。体温上暴は2 例に みられた。

C) C S単独治療（2時間後治療開始群）

a) $\mathrm{C} \mathrm{S} 25 \mathrm{mg}$

第諘A）（a）のごとく，発赤腫脹は一定し ないようであるが，中等度に変化をみる例が多 く，No. 315 では壊死をも伴なつている．菌血症 は，No. 265 の 1 例を除き 6 例に高度の菌が認め られる。すなわ，全例中 100 集落以下の検出は わずか 4 回のみで，そのほかは相当に菌数は多 く，2,000 集落以上の㮥出は10回に及九だ．局所 の菌も全例に検出され，体重減少は5例にみられ， $100 \mathrm{~g}$ 以上最高 $390 \mathrm{~g}$ 末で谢定された。体温上昇 はNo. 264 の $2.1^{\circ} \mathrm{C}$ を最高に，5例にみられた。

b) C S $0.5 \mathrm{mg}$

発赤腫脤は比較的なお著明で，対照と注ぶ同样 で，局所の菌は 2 例に検出され，体温上昇 2 例， 
Table III. Group treated with Cortisone alone.

A) Group in which treated cons initiated 2 Rours iffer in oculation:

(a) CS25mg

\begin{tabular}{|c|c|c|c|c|c|c|c|}
\hline No. of & Skim & & & & & & Rise of \\
\hline rabbito & change & 24 & 48 & & $\begin{array}{l}\text { hours } \\
96\end{array}$ & 100 & temperatures \\
\hline $\begin{array}{l}263 \\
264\end{array}$ & $\begin{array}{l}+ \\
+\end{array}$ & $\begin{array}{l}20001 \\
20000\end{array}$ & 2000 or & $200000^{\circ}$ & $\begin{array}{l}38 \\
120\end{array}$ & + & + \\
\hline & & 680 & 0 & 0 & & & \\
\hline 313 & \# & 1040 & 560. & 2000 of & 1000 & t & + \\
\hline 318 & & $\begin{array}{c}13220 \\
448\end{array} \mid$ & $20000^{2}$ & . $\begin{array}{l}800 \\
2000\end{array}$ & $\left|\begin{array}{l}11 \\
200\end{array}\right|$ & + & 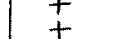 \\
\hline & & & & $A$ & 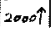 & & r \\
\hline
\end{tabular}

(b) $\underline{C S 0.5 \mathrm{mg}}$

\begin{tabular}{l|l|l|l|l|l|l|l}
\hline 269 & $\#$ & 0 & 0 & 0 & 7 & \pm & \pm \\
270 & +1 & 0 & 0 & 0 & 5 & \pm & \pm \\
271 & $H$ & 0 & 0 & 0 & 0 & + & +
\end{tabular}

体重減少も2 例に認められた，菌血症は少ないけ れども，時間的観察におけるものでは，対照とほ ぶ同様の成續である（第正表（b））.

D） Pc とC S 併用治療

1) 2 時間後治療開始群

a) PPc 5 万U $+\mathrm{C} \mathrm{S} 25 \mathrm{mg}$

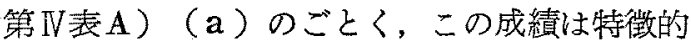
である，局所変化の発赤腫脹は，著明に軽減され ている. No. 320 を除いては，ほとんど変化は認 められない。また菌血症は，No.482の1例のみ に48時間以後96時間まで認められ，他の9例は陰 性である，局所の菌は2例に検出され，体重減少 5 例，体温上昇は 4 例に認められた。

b) PPc 5 万U+C $0.5 \mathrm{mg}$

局所の変化は比較的軽微であるが，上述のC S 25mg群上り明らかに強く, 菌血症抢よび体重減少 は全例にみられなかつた。局所の菌陽性例と体 温上昇例は各 1 例にすぎかつた（第 $V$ 表 $A$ ） (b) ).

c) Pc 1,000 U+C S $25 \mathrm{mg}$

第 $\mathrm{V}$ 表 $A$ ）（c）のごとく，局所反応は中等度 に発現するが，罱死は全例に認められない，体温 は全例に上开があり，体重減少は 1 例のみであつ た。菌血症は著明に増加し，菌数も多く，2,000集 落以上 9 回検出している．局所の菌は全例に検出 されていない。
Table IV. Group treated with Penicillin and Cortisone.

A) Group in which terented word initiated 2 hours after inoculation.

(a) PPC 50,000 u, and CS25 $\mathrm{mg}$

\begin{tabular}{|c|c|c|c|c|c|c|c|}
\hline No. of & Skin & Bac & Enial & num. & ber & Wright- & Rive of \\
\hline rabuts & change & 24 & 148 & 72 & 96 & loos & Tomperature \\
\hline $\begin{array}{l}3 / 7 \\
3 / 8\end{array}$ & 1 & $\begin{array}{l}0 \\
0\end{array}$ & 0 & 0 & 0 & & $\bar{F}$ \\
\hline 319 & \pm & $\sigma$ & 0 & $o$ & 。 & i & - \\
\hline 320 & + & 0 & 0 & $\circ$ & $\therefore$ & + & \\
\hline $\begin{array}{l}81 \\
482\end{array}$ & 主 & : & 1760 & 66 & 41 & + & + \\
\hline 48 & \pm & 0 & $\circ$ & 0 & 0 & & \\
\hline 48 & \pm & $\theta$ & 0 & 0 & 0 & - & \\
\hline $\begin{array}{l}783 \\
486\end{array}$ & - & 0 & 0 & : & 0 & $=$ & $T$ \\
\hline
\end{tabular}

(b) PPC50,000 U. and C $50,5 \mathrm{mg}$

\begin{tabular}{l|l|l|l|l|l|l|l}
\hline 149 & \pm & 0 & 0 & 0 & 0 & \pm & $=$ \\
150 & +1 & 0 & 0 & 0 & 0 & \pm & $=$ \\
185 & \pm & 0 & 0 & 0 & 0 & \pm & $=$ \\
195 & + & 0 & 0 & 0 & 0 & \pm & \pm
\end{tabular}

(C) $\mathrm{PC} 1,000 \mathrm{U}$. and CS25 mg

\begin{tabular}{c|c|c|c|c|c|c|c}
\hline 243 & $H$ & 20001 & 2000 & 56 & 0 & \pm & + \\
244 & + & 20001 & 2000 & 48 & 0 & \pm & + \\
245 & + & 20001 & 2000 & 2000 & 20004 & + & + \\
246 & + & 2000 & 38 & 18 & 22 & - & +
\end{tabular}

(d) $\mathrm{PC} 1000 \mathrm{u}$ and C.S0.5 $\mathrm{mg}$

\begin{tabular}{c|c|c|c|c|c|c|c}
\hline 249 & $H$ & 0 & 2000 & 0 & 0 & - & + \\
248 & $+H$ & 3 & 2 & 0 & 9 & + & + \\
249 & $H$ & 2 & 13 & 0 & 0 & \pm & + \\
250 & $H$ & 2000 & 20000 & 18 & 0 & + & +
\end{tabular}

Table V. Group treated with Penicillin and Cortisone.

B) Group in which treated was initiated 5 hours aster incoulation.

(a) PPC 300,000 U and CS25 m

\begin{tabular}{|c|c|c|c|c|c|c|c|}
\hline 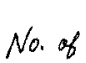 & 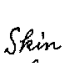 & Bast & & that & & & ise of \\
\hline rabbito & change & 24 & 48 & 72 & $\begin{array}{l}\text { houses } \\
\text { co }\end{array}$ & & Herposiature \\
\hline $\begin{array}{l}418 \\
419\end{array}$ & $t$ & i & $:$ & $\begin{array}{l}7 \\
0\end{array}$ & $\begin{array}{l}0 \\
0\end{array}$ & \pm & - \\
\hline 4 & $\frac{ \pm}{+}$ & 0 & $:$ & 0 & $:$ & \pm & $\overline{-}$ \\
\hline
\end{tabular}

C) Group in whish treated wres initiated 24 howns after inoculation.

(a) Ppe50,000U. and C $\$ 25 \mathrm{mg}$

\begin{tabular}{l|c|c|c|c|c|c|c}
\hline 255 & \# & 20000 & 2 & 0 & 0 & + & $=$ \\
256 & + & 0 & 0 & 0 & 0 & + & $=$ \\
257 & \# & 2000 & 0 & 0 & 0 & + & $=$ \\
258 & H & 20000 & 5 & 0 & 0 & + & $=$
\end{tabular}

d) Pc 1,000 U+C S $0.5 \mathrm{mg}$

発赤腫脹は比較的著明であり, 局所の菌は 1 例 
Table VI. Group treated with 1,000U. Penicillin (2 hours after inoculation).

\begin{tabular}{|c|c|c|c|c|c|c|c|c|}
\hline \multicolumn{4}{|c|}{ Shin change $(\%)$} & \multirow[b]{2}{*}{ Treatinent } & \multirow[b]{2}{*}{ Case } & \multicolumn{3}{|c|}{$\begin{array}{l}\text { Prantage of detecting becteria } \\
\text { in blood }\end{array}$} \\
\hline -, \pm & + & $H$ & H & & & 24 & 48 & \begin{tabular}{l|l}
72 & houns \\
96
\end{tabular} \\
\hline 0 & 0 & $\begin{array}{r}57 \\
\left(\frac{8}{14}\right) \\
\end{array}$ & $\begin{array}{c}43 \\
\left(\frac{6}{14}\right)\end{array}$ & $\begin{array}{c}\text { non-treated } \\
\text { group }\end{array}$ & 14 & $\begin{array}{c}64 \\
\left(\frac{9}{14}\right)\end{array}$ & $\begin{array}{l}64 \\
\left(\frac{9}{14}\right)\end{array}$ & $\begin{array}{cc}50 & 43 \\
\left(\frac{7}{14}\right) & \left(\frac{6}{14}\right)\end{array}$ \\
\hline 0 & 0 & $\begin{array}{c}50 \\
\left(\frac{2}{4}\right)\end{array}$ & $\begin{array}{l}50 \\
\left(\frac{2}{4}\right)\end{array}$ & $p$ & 4 & $\begin{array}{c}75 \\
\left(\frac{3}{4}\right)\end{array}$ & $\begin{array}{l}100 \\
\left(\frac{4}{4}\right)\end{array}$ & $\begin{array}{cc}100 & 25 \\
\left(\frac{4}{4}\right) & \left(\frac{1}{4}\right)\end{array}$ \\
\hline 0 & 0 & $\begin{array}{r}75 \\
\left(\frac{3}{4}\right) \\
\end{array}$ & $\begin{array}{c}25 \\
\left(\frac{1}{4}\right) \\
\end{array}$ & $\begin{array}{l}\mathrm{PCl}, 000 \mathrm{k} . \\
\text { and } \\
\mathrm{CS} 0.5 \mathrm{mg}\end{array}$ & 4 & $\begin{array}{c}50 \\
\left(\frac{2}{4}\right)\end{array}$ & $\begin{array}{l}100 \\
\left(\frac{4}{4}\right)\end{array}$ & $\begin{array}{c}25 \\
\left(\frac{1}{4}\right)\left(\frac{1}{4}\right)\end{array}$ \\
\hline 3 & 0 & $\begin{array}{l}100 \\
\left(\frac{4}{4}\right)\end{array}$ & 0 & $\mid \begin{array}{l}P C 1,000 \mathrm{u} . \\
\text { and } \\
C S 25 \mathrm{mg}\end{array}$ & 4 & $\begin{array}{l}100 \\
\left(\frac{4}{4}\right)\end{array}$ & $\begin{array}{l}100 \\
\left(\frac{4}{4}\right)\end{array}$ & $\begin{array}{cc}100 & 50 \\
\left(\frac{4}{4}\right) & \left(\frac{2}{4}\right)\end{array}$ \\
\hline
\end{tabular}

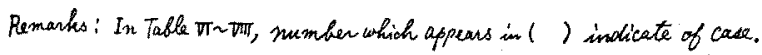

に，体重減少は 2 例，体温上昇は 3 例に認められ た。菌血症も比較的多く, 2,000 集落以上 3 回検 出されている（第 $V$ 表A）（d））.

2) 5 時間後治療閉始群

PPc 30万UとC S 25mg の併用成績では, 局所 の変化はかなり軽減され，流血中の菌は，1例の みに72時間に7集落認められ，体温上昇は 1 例 で，局所の菌は全例陰性であつた（第 V表B）

(a)).

3） 24 時間後治療開始群

PPc 5 万UとC S 25mg の垪用成績では，治療
聞始後に菌はすみやかに消失するが，48時間後 2 例に，2 2 および 5 集落流血中より菌が検出された のみで, 他のものは陰性であつた。局所の発赤腫 脹は急速に軽減される傾向はなく，比較的著明で ある，体温上昇は，治療開始後は全例に認められ ず，体重は全例に減少がみられた（第 $V$ 表 $C ）)$.

E) 実鈳成續の小括

以上の実験成續より，2時間後治療群（第 I図 $\mathrm{A}, \mathrm{C}$ 型式) 中 $\mathrm{Pc}$ 少量 $(1,000 \mathrm{U})$ 治療群の成 續を一括表示すると第VI表のごとくで,Pc 1,000 U単獨投与では，無治療詨照とほとんぞ皮膚変化

Table VII. Group treated with 50,000U. Procaine Penicillin (2 hours after inoculation).

\begin{tabular}{|c|c|c|c|c|c|c|c|c|c|}
\hline \multicolumn{4}{|c|}{ Skin change $(\%)$} & \multirow[b]{2}{*}{ Treatment } & \multirow[b]{2}{*}{ Case } & \multicolumn{4}{|c|}{$\begin{array}{l}\text { Percentage of detecting bacteria } \\
\text { in blood }\end{array}$} \\
\hline- \pm & + & $H$ & $\mathrm{HH}$ & & & 24 & 48 & 72 & $\begin{array}{l}\text { hoous } \\
96\end{array}$ \\
\hline 0 & 0 & $\begin{array}{l}57 \\
\left(\frac{8}{14}\right)\end{array}$ & $\begin{array}{c}43 \\
\left(\frac{6}{14}\right)\end{array}$ & $\begin{array}{c}\text { non-treated } \\
\text { group }\end{array}$ & 14 & $\left(\frac{64}{14}\right)$ & $\left(\begin{array}{c}64 \\
14\end{array}\right)$ & $\begin{array}{c}50 \\
\left(\frac{7}{14}\right) \\
\end{array}$ & $\begin{array}{l}43 \\
\left(\frac{6}{14}\right)\end{array}$ \\
\hline $\begin{array}{c}33 \\
\left(\frac{3}{9}\right)\end{array}$ & $\begin{array}{l}2.2 \\
\left(\frac{2}{4}\right)\end{array}$ & $\begin{array}{l}45 \\
\left(\frac{4}{9}\right) \\
\end{array}$ & 0 & ppc 50,000u & 9 & 0 & $\begin{array}{c}22 \\
\left(\frac{2}{4}\right)\end{array}$ & 0 & 0 \\
\hline $\begin{array}{l}60 \\
\left(\frac{3}{5}\right) \\
\end{array}$ & $\begin{array}{c}20 \\
\left(\frac{1}{5}\right) \\
\end{array}$ & $\begin{array}{l}20 \\
\left(\frac{1}{5}\right)\end{array}$ & 0 & $\begin{array}{l}\text { PpC50,000 U. } \\
\text { and } \\
C S 0.5 \mathrm{mg}\end{array}$ & 5 & 0 & 0 & 0 & 0 \\
\hline $\begin{array}{l}90 \\
\left(\frac{9}{10}\right)\end{array}$ & $\begin{array}{l}10 \\
\left(\frac{1}{10}\right)\end{array}$ & 0 & 0 & $\left|\begin{array}{c}\mathrm{PPC} 50,000 \mathrm{U} \\
\text { and } \\
\mathrm{CS} 25 \mathrm{mg}\end{array}\right|$ & 10 & 0 & $\begin{array}{l}10 \\
\left(\frac{1}{10}\right)\end{array}$ & $\left(\frac{1}{10}\right)$ & $\begin{array}{l}10 \\
\left(\frac{1}{10}\right)\end{array}$ \\
\hline
\end{tabular}


Table VIII. Comparison of time from which treatment was initiated.

\begin{tabular}{|c|c|c|c|c|c|c|}
\hline & \multirow[b]{2}{*}{ Treatment } & \multirow[b]{2}{*}{ Care } & \multicolumn{4}{|c|}{ Shim change (to) } \\
\hline & & &,- \pm & + & + & H+ \\
\hline $\begin{array}{c}2 \\
\text { Houns }\end{array}$ & $\left\{\begin{array}{c}\operatorname{PPC} 50,000 \mathrm{U} \\
\text { and } \\
\operatorname{CS} 25 \mathrm{yy}\end{array}\right.$ & 10 & $\begin{array}{l}90 \\
\left(\frac{9}{10}\right)\end{array}$ & $\begin{array}{l}10 \\
\left(\frac{1}{10}\right)\end{array}$ & 0 & 0 \\
\hline 5 & PPC 300,000 k & 5 & 0 & o & $\begin{array}{l}80 \\
\left(\frac{4}{5}\right)\end{array}$ & $\begin{array}{c}20 \\
\left(\frac{1}{5}\right)\end{array}$ \\
\hline Houns & $\begin{array}{l}\mathrm{PPC} 300,000 \mathrm{u} \\
\text { and } \\
\mathrm{CS} 25 \mathrm{mg}\end{array}$ & 4 & $\begin{array}{c}25 \\
\left(\frac{1}{4}\right)\end{array}$ & $\begin{array}{c}50 \\
\left(\frac{2}{4}\right)\end{array}$ & $\begin{array}{c}25 \\
\left(\frac{1}{4}\right)\end{array}$ & 0 \\
\hline $\begin{array}{l}24 \\
\text { Hoars }\end{array}$ & $\left|\begin{array}{l}P p C 50,000 \mathrm{~K} \\
\text { and } \\
C S 25 \mathrm{mg}\end{array}\right|$ & 4 & 0 & $\begin{array}{c}25 \\
\left(\frac{1}{4}\right)\end{array}$ & $\begin{array}{l}50 \\
\left(\frac{2}{4}\right)\end{array}$ & $\begin{array}{l}25 \\
\left(\frac{1}{4}\right)\end{array}$ \\
\hline
\end{tabular}

ならびに菌血症は変化を認めない。

これにCS 0.5mgの少量併用では，単獨のもの と大差なく，C S の影響 がほとんど認められな いＣＳ25mgの併用では，むしろ菌血症は増加し ている.

これは，CS大量による菌血症助長を，少量の $\mathrm{Pc}$ では抑制しないことを示晙している。

つぎに，PPc 大量（ 5 万U）併用群の成續を まとめると第叫表 の示すとおりで，PPc 5 万U 単獨投与のものでは，皮膚変化は比較的軽減さ れ，完全ではないが菌血症の抑制がみられる。

これとCS $0.5 \mathrm{mg}$ 少量併用では，影響は単獨 のものとあまり著しい差はない，ところが，CS 25mgの大量を併用すると，はじめて皮虞桨化は著 明に軽減され，菌血症の助長も全く認られない。

さらに，治療開始時間に上る影響を検討すると 第林表のごとくで, 菌接種後, 皮䖉の炎症区応が すでに高度に達したと思われる24時間後では, 感 染早期 ( 2 時間後)に使用して著しい効果を示した PPc 5 万UとC S 25mgの併用を行なつても, 皮 䖒の变化の軽減は明らかでなく，感染早期治潦群 と較ぺて著しく劣つている。この效果の著しい相 違は，感染症の炎症過程に対する併用時期の違い によるものである。

\section{IV 考 案}

実験的感染症における副腎ステロイド投与に関 する文献上，Mogabgab 3 は A 群溶連菌を家鬼皮 内に接種し，菌接種4 日前よりC S50mgを連続投 与したが，全例に敗血症を認め，2〜12日で死亡
したといい，また彼6)は，同様の奏験で，3日前 より C S 12mgの連続投与を76例に行ない，71例が 2 週間以内に死亡した，対炤群では，86例中 3 例 のみが死亡したという。

Robinson ${ }^{4}$ 注肺资球菌 I 型を用いた同様の夹 歌で，7日前よりC S 1 3 mg/kg を連続投与し たところ，局所反応は軽減するが，菌血症は助長 され，4〜10日で全例死亡したと述べている.

Germuth $^{52}$ は前者と同様の实験で，1日前よ り $15 \mathrm{mg} / \mathrm{kg} の \mathrm{CS}$ を投与し，感染後も $10 \mathrm{mg} / \mathrm{kg}$ を投 与したが，下熱効果は対照群と大差なく，菌血症 は助長され，局所の菌の増殖も増大され，さらに 死亡率も大であつたと報告している。

著者の実験でも，C S 25mg単独治療では，菌血 症は明らかに助長され, 局所の菌検出も多く, 体 重減少も著明で，また体温下降の傾向はほとんど みられない。

これらの成續からみると，感染症に刘するC S 単獨投与は，生体に不利な影響を及涩すことが推 察され，ことに大量の場合には，その影響が影著 である。

抗生剂と副腎ステロイドの併用実験として, Mogabgab $\left.{ }^{6}\right)$ は上述の実験で，菌接種 3 日前より C S 12mg 㐎連続投与し, 感染 3 日目より C Sに Pc 40万Uを10例に併用したところ， 3 例が死亡 し，残りの7例に，さらに4日間併用を続けたと ころ，血液中に菌は認められず生存した。

この事実より Mogabgab ${ }^{6}$ は，感染3日目に 大量の $\mathrm{Pc}(40$ 万 $\mathrm{U})$ と， CSとを併用しても， 明暸な併用效果は認められないと迅へててい.

この実駼は菌接種後すでに3日も経過してか ら， Pc， Cs の併用を開始したという点に問題が ある。

すなわち，著者の成績では第相表にみられるご とく, 菌接種 2 時間後併用群と 24 時間後併用群と を比較すると䁛述のように，後者では局所変化の 軽減は僅少であるが，前者では著效を得ている。

この成繢よりみると, 併用時期は当然, 感染早 期（2時閒後）に行なうべきであり，菌接種 3 日 後では遲きに失するといえよう。

また Jawetz $z^{7}$ は，マウスに種々なる菌による 
感染実験を行ない,これに1日0.15mgのC Sを種 マなる抗生刜と併用している。

以上の実験で，劇症例ではC Sに大量の抗生戍 を併用しても，抗生剂単独使用群に比し明ら私に 死亡率が高く，C S の悪影響を認めている. 軽症

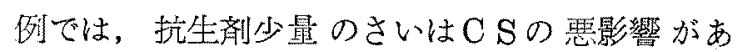
り。抗生绪大量併用時のみ, 覀影響の消失を認め ている.

結論的には，本論文は劇症のさいはもちろん， 楼症のさいでも，積極的併用效果を認めず，単に C S の悪影響の有無についてのみ論じている.

積極的併用效果を認めなかつた理由の一つに は，CS㧍よび各種抗生剂の量的検討が不充分で あったことがあげられる。

同憭蔵原は，マウスの肺炎球菌による劇症感染 に Pc，CS を併用した結果，比較的充分量の Pc とCSとの併用では，Pc 単独に比し明睹な死亡 率の低下を認め，Pc 量が不足のさい，あるいは C S 量が大量に失したときなどでは，いずれも併 用效果は認められず，むしろ死亡率の増加を招来 した場合があつた。

著者の成績でも，動物，笑験方法等が異なつて はいるが，第林表のごとく PPc 5 万UとC S 25 mgの併用群に最も顯著に菌血症並びに局所所見の 喤減至得ている。

実騟的感染症に刘する抗生剂と副腎ステロイド 併用に関する文献は，Mogabgab ${ }^{6}$, Jawet $z^{7}$ ら の成績を始め，その多(は8) 11)16)17)18)，悪影響 を認めている，わずかに Jawet $z^{7}$ の成績の一部 分拀よび Robinson ${ }^{4}$ の家鬼皮内肺炎球菌感染症 で，大量のPcを併用したときのみに，C Sの悪 影響除去の事实を認めているにすざず，いずれも 積極的な併用効果については諭じていない.

以上通覧するに，いずれもC Sおよび Pcの投 与量ならびに併用開始時期に関する詳細な梌討䚮 なされていない。

著者の成績より，この点に関する見解を述べれ ば，以下のごとくである。

投与時期については，CSの抗炎症効果を発揮 活用せしめる意味からも，感染早期に併用すべき であり，既述（第林表）のと㧍り，感染早期併用
群（菌接種 2 時間後）のみが好成續を得ている. これは菌接種24時間後併用開始群のごとく，局 所の病変がある程度まで完成されたものでは，充 分効果が発揮されず，感染早期使用によつてのみ 併用效果をあげ得ることを示している.

抗生剤投与量については，Pc 1,000 UとC S $25 \mathrm{mg}$ の併用では，Pc 1,000 U単独治療より菌血 症屺し万助長されるが（第江表）ＰPC 5 万U とC S25mgの併用では，PPc 5 万U単独より菌 血症は助長されない(第VII表).

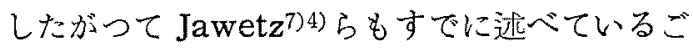
とく，CSに抗生風併用を行なう場は，必ず抗生 用単独投与時より大量使用すべきを確認した。

つぎにCSの併用量に関しては，PPc 5 万U とC S 0.5mgの併用では， PPc 単独と相違はみ られないが，大量のC S 25mgを併用すれば，著し い效果吕得られる（第林表）。

このことは，C Sが少量では生体に影響を及ほ すことは少ないが，大量のさいは，その強力な抗 炎症作用のため，局所所見の著しい軽減がみられ る、しかしながら区面，生体防衙機能低下による 菌血症助長作用は当然堌強されるはずであるが, 大量の PPc との併用により，この菌血症も抑制 され，好結果を得たものであろう。

なお，以上の局所所見ならびに菌血症両者に対 する效果は, 果して Pc 単独では得られるや否や を検討すると，第林表のごとく PPc 5 万UとC S25mgの併用群では, 明らかに PPc 5 万Uより 好成績を得，またさらに大量 PPc 30 万U投与 (第怔表)のさいも，C S 25mg併用により，Pc 単 独では得られない局所所見の好転をみている。

この事実は，抗生戍のみでは得られない勃果を C S 併用により発揮されたものとして, 強調さる ベきである。

以上, 諸家の報告と著者の成績とを比較検討し て来たが，本実験は1回治療のみであつたが，さ らに数回の併用治療, あるいは挄生剤のみを引綕

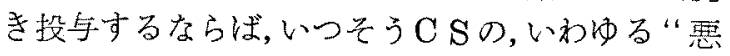
影響” の発現を完全に抑制し，同時にCSの抗炎 症作用を充分に利用することができるものと考え 
られ，臨床応用にも，大いに活用し得るものと確 信するものである。

\section{$\mathbf{V}$ 結 論}

感染症の执生用治害に及ぼす副箐ステロイトの

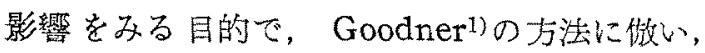
家雨皮内に肺炎球菌 I 型 $100 \mathrm{~A}$ 株を接種した。

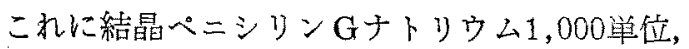
縣濁水性プロカインペニシリン 5 万単位または30 万笚位と，コーチゾンアセテート0.5mg〜25mgを, それそれ，単独あるいは併用治療を夷施した。

治療開始時期は, 菌接種 $2 ， 5 ， 24$ 時閒後に 1 回のみ行なつた。併用のさいは，C S と Pck同 時に筋注した。

以上の結果，以下のごとき成續を得た。

1) 菌接種 2 時間後に, 少量のPc $(1,000$ U) と大量のC S (25mg) との併用では，C Sの 抗炎症作用により，局所所見に若干の効果をみる が，Pc 少量なるため， C S の菌血症助長作用は 防ぎきれい。

2) 同様, 大量の Pc 単独治療 (PPc 5 万U) では，菌血症はみられず，局所所見も軽度ではあ るが，な掕出性变化が明らかにみられる。

3）ところが，Pc とCSともに大量の併用で は，大量のPcにより菌血症の助長も全くみず， しかも，局所所見に刘して著しい效果を示し，渗

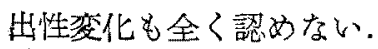

4）菌接種後24時間では，Pc，CSともに大量 の併用を行なつても，好影響はみられなかつた。 結論的には，Pc， CS の併用は感染早期に，し亦 \& $\mathrm{Pc}, \mathrm{Cs}$ ともに大量併用した場合のみ, Pc 単 独使用では得られない好影響を得ることができ る。

(本論文の一部恃, 籍 6 回日本化学䗷法学会総会に括 いて笔表した).

\section{文献}

1) Goodner, K.: Experimental intradermal pneumococcus infection in rabbits. J. Ex.

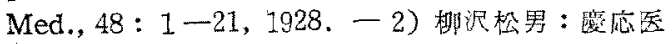
学揭载子定. - 3) Mogabgab, W.J., \& Thomas,
L.: The effects of cortisone on experimental infection with Group A Streptococci in rabbits. J. Lab. \& Cl. Med., $36: 968,1950$. -4) Robinson, H.J.: Effects of cortisone on intradermal pneumococcal infection in rabbits. Fed. Proc., 10:332, 1951. - 5) Germuth, F. G., et al.: The influence of cortisone on the evolution of acute infection and the development of immunity. Bull. Johns Hop. Hosp., 91 : 22-48, 1952. - 6) Mogabgab, W.J., \& Thomas, L.: The effects of cortisone on bacterial infection in rabbits. J. Lab. \& Cl. Med., 39:271-289, 1952. - 7) Jawetz, E.: Effect of cortisone on therapeutic efficacy of antibiotics in experimental infections. Arch. Int. Med., 93:850-862, 1954. - 8) Smith, J.M., et al.: Effect of adrenal hormons of infection of mice with pneumonia virus of mice (P.V. M.). Proc. Soc. Ex. Biol. Med., 78 : 505-510, 1951. - 9) Thomas, L.: The effects of cortisone and adrenocorticotropic hormone on infection. Ann. Rev. Med., 3: $1-20,1952$. 10) Jahn, J.P., et al.: The combination of ACTH-Cortisone-Hydrocortisone with antibiotics in the management of overwhelminly severe infections. J. Ped., $44: 640-657,1954$. 11) Kass, E.T., et al.: Effects of adrenal steroids on resistence to infection. Arch. Int. Med., 96 : 397-402, $1955 .-12$ ) Kinsell, L. W., \& Jahn, J.P.: Combined hormonal-antibiotic therapy in patients with fluminating infections. Arch. Int. Med., $96: 418-427,1955$. -13) Kern, R.A.: The use and abuse of steroid therapy, notably in allergic disorders. Am. J. Med. Sc., 233 : 430-447, 1957. 14) Smith, P.N.: Antibiotics and host resistance. Brit. Med. J., $129-133,1957 .-15$ ) Spink, W.W.: ACTH and adrenocorticosteroids as therapeutic adjuncts in infectious diseases. New Eng. J. Med., 257: 979-983, 1957. -16) Kass, E.H., \& Finland, M.: Adrenocortical hormones in infection and immunity. Ann. Rev. Micro., 7 : 361-388, 1953. - 17) Thomas, L.: Cortisone, ACTH and infection, Bull. New York Acad. Med., 3 : 487-499, 1955. - 18) Kass, E.H., \& Finland, M.: Adrenocortical hormones and management of infection Ann. Rev. Med., 8: 1-18, 1957. 一19）勝正孝: 感染症炕刘吉古副肾ステロイド抗 生㣚の併用. Chemotherapy., 6 ：265-273, 昭 33. 一20）真下啓明：抗生物質・抗炎症木ルモン併 用の意嶬. Chemotherapy., $6: 259-264$, 昭33. 